\title{
Odgovorno informiranje i financijsko obrazovanje kao mjerilo učinkovite građanskopravne i socijalne zaštite potrošača ${ }^{1}$
}

\author{
KSENIJA GRUBIŠIĆ* \\ Pravni fakultet Sveučilišta u Zagrebu \\ Zagreb, Hrvatska
}

Izvorni znanstveni rad

UDK: 366.6

doi: $10.3935 /$ rsp.v25i3.1524

Primljeno: siječanj 2018.

Postoje različiti pristupi tumačenja uzroka sve veće prezaduženosti građana: ekonomski, socijalni, pravni. Takvo povećanje zasigurno je jedna od posljedica financijske krize. Međutim, sve veća dostupnost te raznolikost ponude financijskih usluga, nerazumijevanje pojmova, odnosno temeljnih prava $i$ obveza koje proizlaze iz ugovaranja takvih usluga, također doprinosi porastu zaduženja. Stoga, temeljno pitanje na koje se nastoji odgovoriti u radu jest: u kojoj mjeri je poznavanje prava i obveza građana koji koriste financijske $i$ javne usluge vjerodostojno mjerilo učinkovitosti građanskopravnih propisa kojima bi se, među ostalim, trebala štititi i socijalna prava, s obzirom da njihova primjena utječe na status (pre)zaduženosti građana? Odgovori na navedeno pitanje velikim se dijelom temelje na rezultatima empirijskih istraživanja provedenih u listopadu 2016. u okviru projekta Građanskopravna zaštita građana u financijskoj krizi. Ti rezultati razmatrani su u kontekstu temeljnih vrijednosti izraženih pojedinim načelima modela odgovornog kreditiranja kao i pojedinim načelima europskog socijalnog modela. Prvenstveno je riječ o načelu zaštite potrošača koje povezuje oba modela, a čije ostvarivanje pretpostavlja određeno usklađivanje pojedinih dijelova građanskopravne i socijalne zaštite građana. Temeljem rezultata istraživanja, $u$ radu se analizira $u$ kojoj mjeri su pojedine privatnopravne norme, posebice one koje određuju način informiranja građana pri korištenju financijskih te pojedinih javnih usluga, društveno učinkovite, što otvara potrebu uvođenja učinkovitije pravne i nepravne zaštite građana kako bi se smanjila njihova financijska, a time $i$ socijalna isključenost.

Ključne riječi: model odgovornog kreditiranja, europski socijalni model, zaštita potrošača, financijske usluge, javne usluge, informiranost, financijsko obrazovanje i opismenjavanje.

\footnotetext{
${ }^{1}$ Ovaj rad sufinancirala je Hrvatska zaklada za znanost projektom broj 5269 Građanskopravna zaštita građana u financijskoj krizi/CitiProtect (http://citprotect.pravo.unizg.hr/).

* Ksenija Grubišić, Pravni fakultet Sveučilišta u Zagrebu / Faculty of Law, University of Zagreb, Trg Republike Hrvatske 14, 10000 Zagreb, Hrvatska / Croatia, ksenija.grubisic@pravo.hr
} 


\section{UVOD}

U kojoj mjeri je poznavanje prava i obveza građana koji koriste financijske $i$ javne usluge vjerodostojno mjerilo učinkovitosti građanskopravnih propisa kojima bi se, među ostalim, trebala štititi i socijalna prava, s obzirom da njihova primjena utječe na status (pre)zaduženosti građana? Odgovori na navedeno pitanje u ovom radu dobrim dijelom se temelje na rezultatima empirijskih istraživanja provedenih u listopadu 2016. u okviru projekta Građanskopravna zaštita građana u financijskoj krizi. Glavni cilj projekta bio je istražiti u kojoj mjeri i na koji način različiti građanskopravni instrumenti, njihovo pravno uređenje te primjena utječu na sprječavanje i prevladavanje financijskih teškoća građana prilikom ispunjavanja novčanih obveza, te ponuditi moguća rješenja za unaprjeđenje normativnog i nenormativnog okvira, koja bi doprinijela učinkovitijem ostvarivanju građanskopravne zaštite građana. Polazilo se od hipoteze da instrumenti građanskog prava imaju važnu ulogu pri zaštiti građana u financijskim poteškoćama, međutim njihova međusobna neusklađenost istovremeno je do određene mjere doprinijela tim poteškoćama. U prvoj godini projekta napravljena je teoretska analiza postojećeg pravnog uređenja, što je imalo za posljedicu i određivanje hipoteza o postojećim situacijama te mogućnostima za njihovo poboljšanje koje će se testirati empirijskim putem.

Projekt je podijeljen u pet istraživačkih, međusobno povezanih, tema²:

1. istraživanje pravnih modela predugovornih obveza trgovca za informiranje građana o njihovim ugovornim pravima i obvezama
2. istraživanje pravnog modela odgovornog kreditiranja

3. istraživanje modela za zaštitu građana u slučaju pogoršanja financijske situacije zbog nemogućnosti ispunjenja novčanih obveza

4. istraživanje alternativnih načina dobrovoljnog ispunjenja novčanih obveza

5. istraživanje modela građanskopravne zaštite građana u naplati istraživanja.

U ovom radu prikazat ću pojedine rezultate koji pokazuju učinkovitost pravnog modela odgovornog kreditiranja. Ti rezultati bit će razmatrani u kontekstu temeljnih vrijednosti izraženih pojedinim načelima istaknutog modela kao i pojedinim načelima europskog socijalnog modela. Prvenstveno mislim na načelo zaštite potrošača koje povezuje oba modela, a čije ostvarivanje pretpostavlja određeno usklađivanje pojedinih dijelova građanskopravne i socijalne zaštite građana. Drugim riječima, temeljem rezultata empirijskih istraživanja, prikazat ću u kojoj mjeri su pojedine privatnopravne norme koje se odnose na zaštitu potrošača društveno učinkovite ${ }^{3}$, pri čemu prvenstveno mislim na one norme koje određuju način informiranja građana pri korištenju financijskih te pojedinih javnih usluga. Uvjerenja sam kako su upravo te norme one koje bi trebale pružati zaštitu od prekomjerne zaduženosti građana. Pritom, jedan od pokazatelja njihove učinkovitosti zasigurno je i (ne)razumijevanje temeljnih pravnih pojmova i modela građanskopravne zaštite. Ovakav pristup svojstven sociologiji prava nerijetko se primjenjuje kod istraživanja načina i razloga

\footnotetext{
${ }^{2}$ Svih pet podtema u svojim ciljevima usklađeno je s mjerama Europske komisije koje potiču sustav sprječavanja i ublažavanja osobne prezaduženosti. To su: 1. prevencija, 2. pomaganje, rješavanje i rehabilitacija te 3. rješavanje problema koji nastaju na financijskom tržištu (European Commission, 2013.b; Bejaković, 2016.: 145).

${ }^{3}$ Detaljnije o društvenoj učinkovitosti prava u Bryde (1993.: 7-12).
} 
korištenja financijskih usluga, ponajviše kredita, gdje se pored financijskih učinaka (bankarskog te zakonodavnog okvira) procjenjuju i društveni učinci kao što su društvena odgovornost, utjecaj na zdravlje, okruženje, nezaposlenost, obrazovanje itd. (Nieto, Cinca i Cala, 2016.) ${ }^{4}$.

\section{POVEZIVANJE EKONOMSKIH I SOCIJALNIH VRIJEDNOSTI - »EUROPSKI SOCIJALNI MODEL«}

»Europski socijalni model« dio je procesa europeizacije čiji je prioritetni cilj usklađivanje ekonomskih i socijalnih vrijednosti kroz (ne)posredan utjecaj na socijalne politike $\mathrm{s}$ jedne, uz istovremeno utjecanje na rad službi od općeg interesa, s druge strane. Riječ je o modelu koji služi za usmjeravanje nacionalnih politika, u smislu očuvanja nacionalnih modela socijalne države uz koordinaciju europskih institucija. ${ }^{5} \mathrm{U}$ tom smislu, svaka država doprinosi razvoju »europskog socijalnog modela« primjenjujući nacionalne i zajedničke socijalne politike, s obvezom da svake dvije godine podnosi izvješće o načinu i učincima primjene (Puljiz, Bežovan, Matković, Šućur, Zrinščak, 2008.: 57-58). Cijeli taj proces nerijetko se objašnjava i mjeri novim vrijednostima poput $\gg$ socijalne isključenosti«, »zapošljivosti« i »odgovornog kreditiranja«, »osobne prezaduženosti«, »zaštite potrošača«, »obrazovanja potrošača«. Riječ je o pojmovima čija značenja nisu teorijski jednoznačno određena na europskoj razini niti na razini pojedinih država. Naravno, različitosti koje iz toga proizlaze vidljive su i u njihovoj primjeni. Sve to vrijedi i za Republiku Hrvatsku koja je 2003. ratificirala Europsku socijalnu povelju i njezina tri protokola (NN, 15/2002.). Navedeni proces usmjeravanja nakon posljednje financijske krize primjenjuje se u gotovo svim područjima rada službi od općeg interesa.

Temeljem mnogobrojnih Priopćenja Europske komisije, postaje očito kako se "službe od općeg interesa« nalaze u središtu rasprava i promišljanja koncepta o »europskom socijalnom modelu«. Dovoljno je izdvojiti samo Bijelu knjigu o službama od općeg interesa (dalje: Bijela knjiga) u kojoj se navodi kako službe od općeg interesa predstavljaju jedan od stupova europskog modela društva koji zahtijeva zajednički pristup temeljen na sljedećim načelima: univerzalnosti, kontinuitetu, kvaliteti, financijskoj dostupnosti te zaštiti korisnika i potrošača (European Commision, 2004.a; Bijela knjiga, 2006.: 39) ${ }^{6}$.

U kontekstu teme ovog rada važno je naglasiti kako su pojmom »službe od općeg interesa« obuhvaćene dvije vrsti službi: službe od općeg gospodarskog interesa $\mathrm{s}$ užom jezgrom tzv. mrežnih industrija (telekomunikacije, audiovizualno emitiranje, opskrba električnom energijom, opskrba plinom, itd.) te negospodarske službe od općeg interesa kao što su službe u soci-

\footnotetext{
${ }^{4}$ Ovdje je korisno navesti $\mathrm{i}$ istraživanje o ulozi društvenih znanosti u percepciji gospodarstva provedeno uz sudjelovanja sociologa u dvije portugalske maloprodajne banke (Lopes i Marques, 2011.).

${ }^{5}$ Iako se o procesu europeizacije najčešće promišlja kao o političkom procesu, za sveobuhvatnije razumijevanje vrijednosti europskog socijalnog modela kao dijela tog procesa, bilo bi potrebno istražiti i teoretske izvore. Naime, vrijednosti kao što su pravednost, efikasnost, ekonomičnost, socijalna jednakost, socijalna zaštita te njihovo usklađivanje čine okosnicu u tumačenju društvenih promjena niza utjecajnih teoretičara, kao, primjerice, Th. $H$. Marshalla, F. A. Hayeka, A. Giddensa, itd.

${ }^{6}$ Prijevod Bijele knjige objavljen je u časopisu Hrvatska i komparativna javna uprava (2006., 2007.). Pojam »službe od općeg interesa« nije određen Ugovorom o osnivanju Europske zajednice, ali se taj pojam koristi za podjelu odgovornosti između Europske zajednice i država članica. Vidi detaljnije čl. 16. i 86. Ugovora - Treaty Establishing The European Community (2006.).
} 
jalnoj zaštiti, obrazovanju, zdravstvu. Uz očite razlike koje proizlaze iz djelatnosti kojima se te dvije vrste službe bave kao i načinom njihova normiranja, postoji obilježje koje ih povezuje ili bi ih trebalo povezivati a to je - opći interes. Opći interes bi se prvenstveno trebao zaštiti pravnom normom, Ustavom i/ili zakonom, za što naravno postoje različita pravna rješenja ovisno o kojoj vrsti službi je riječ. ${ }^{7}$ Međutim, ono što je ovdje znakovito jest da nerijetko unutar pojedinih vrsti službi, npr. službi od općeg gospodarskog interesa postoji pored zakona i niz općenormativnih podzakonskih akata donesenih od različitih zakonodavnih i regulatornih tijela koja na različite načine uređuju pojedine (srodne) vrste gospodarskih djelatnosti. Takvo mnoštvo propisa otežava preglednost, sistematizaciju te dosljednost u primjeni pravnih normi, što ujedno predstavlja dodatne otegotne okolnosti u osiguravanju općeg interesa njihova rada.

Službe od općeg gospodarskog interesa prepuštaju se uglavnom stvaranju sektorskih tržišta, općenito djelovanju tržišta te ekonomskim vrijednostima u okviru određenih načela. Ponajviše iz razloga da normiraju ta nova tržišta, osnovano je niz agencija s odgovarajućim nadležnostima, koje su u određenoj mjeri nezavisne od zakonodavne i izvršne vlasti. Sve to ujedno znači da je stvoreno i mnoštvo novih propisa kao i tijela nadležna za rad tih službi (Koprić, 2009.). Za razliku od njih, službe od općeg negospodarskog interesa izuzete su od primjene pravila o tržišnom natjecanju. To su službe u koje pripada i područje socijalne zaštite. Riječ je uglavnom o socijalnim službama od općeg interesa koje temeljem Priopćenja Europske komisije iz 2006. obuhvaćaju, među ostalim, socijalne službe čiji je rad usmjeren neposredno na pojedinca te obuhvaća pomoć osobama koje se nalaze u nekoj osobnoj krizi, pomoć pri reintegraciji u društvo i na tržište rada (European Commision, 2006.: 4; Đulabić, 2007.: 151). U ovom kontekstu, zanimljivo je primijetiti kako se pojam »službe od općeg interesa« ne koristi u našem zakonodavstvu (Koprić, 2014). Umjesto tog pojma, češće se koristi pojam »javne službe« iako se u europskim dokumentima, pa tako i u Bijeloj knjizi izričito navodi kako je riječ o pojmovima koji nemaju isto značenje. Pritom nije riječ samo o terminološkoj neusklađenosti jer su pojmom »javne službe«, koji također nije dosljedno proveden u našim propisima ${ }^{8}$, izostavljeni i prepušteni sustavnijem ujednačavanju dijelovi gospodarskih i negospodarskih službi u čijem normiranju bi trebalo biti prepoznato upravo njihovo zajedničko, a ujedno i glavno obilježje kao što je - opći interes.

Uglavnom, rad tih službi trebao bi biti normiran, a potom i vrednovan u primjeni s obzirom na načela »europskog socijalnog modela« (Bijela knjiga, 2007.: 46). Stoga pitanje koje se nameće jest koja načela bi trebala osiguravati opći interes tih službi, a koja bi se prepoznala i u pravnoj normi kojom bi se trebale štititi ekonomske i socijalne vrijednosti na način kako je to idejno zamišljeno u okviru istaknutog modela?

Iako je riječ o načelima koja se odnose na obje vrste službi kako je to izričito navedeno u Bijeloj knjizi, oni zasigurno nemaju jednaku važnost u načinu normiranja svake od njih. Međutim, važno jest to da o njihovoj primjeni ovisi tijek i način daljnjih

${ }^{7}$ U Nacionalnom programu zaštite potrošača za razdoblje od 2013. do 2016. godine (NN, 90/2013.), koji je donio Hrvatski sabor, u poglavlju 2. Pravni temelji politike zaštite potrošača u Republici Hrvatskoj navedeno je preko 30 zakona (bez podzakonskih akata!) koji sadrže pravne norme o zaštiti potrošača u okviru rada pojedinih službi.

${ }^{8}$ Vidi detaljnije u Koprić i Đulabić (2009.). 
usklađivanja ekonomskih i socijalnih vrijednosti. Načela su:

1. omogućiti da javne vlasti djeluju što bliže građanima poštujući pritom načelo supsidijarnosti

2. postići ciljeve javnih službi unutar natjecateljskih otvorenih tržišta kao što su razvoj visokokvalitetnih, financijski dostupnih i pristupačnih službi

3. osigurati povezanost $\mathrm{i}$ univerzalni pristup službama koje se smatraju nužnima te nametnuti obvezu pružateljima službi da ponude točno određene usluge u skladu s preciznim uvjetima, uključujući teritorijalnu pokrivenost i pristupačnu cijenu

4. održavati visoku razinu kvalitete, zaštite i sigurnosti potrošača i korisnika

5. osigurati prava potrošača i korisnika što podrazumijeva teritorijalnu i financijsku dostupnost službi, kao i ostvarivanje svih prethodnih načela, postojanje neovisnih regulatornih tijela $\mathrm{s}$ jasno određenim ovlastima, među ostalim, osiguravanje predstavništva i aktivnog sudjelovanja potrošača i korisnika u vrednovanju službi, raspoloživost prikladnih pravnih lijekova i mogućnosti naknade štete te postojanje evaluacijske klauzule koja omogućava da se standardi obavljanja službe prilagođavaju promjenama i potrebama korisnika i potrošača kao i promjenama u gospodarskom i tehnološkom okruženju

6. vrednovati prikupljene podatke na razini država članica
7. poštovati različitost službi od općeg interesa (zahtjevi zdravstvenih i socijalnih službi od mrežnih službi), te različitih potreba korisnika i potrošača uvjetovanih gospodarskim, društvenim, geografskim ili kulturnim prilikama

8. povećavati transparentnost organiziranja, financiranja, regulacije i vrednovanja službi

9. pravna sigurnost (Bijela knjiga, 2006.: 42-49).

\section{Kriza}

Razdoblje financijske krize bilo je, i jest, svojevrsna »provjera« procesa usklađivanja socijalnih i ekonomskih vrijednosti. Porast broja nezaposlenih, kreditne zaduženosti što dovodi i do porasta siromaštva i socijalne isključenosti, te povećanje duga na mikro- i makrorazini samo su neke od njezinih najčešćih socijalno-ekonomskih posljedica, gdje nerijetko jedna uvjetuje i potencira drugu. Mnoga istraživanja o posljedicama posljednje financijske krize u Hrvatskoj i Europi također dokazuju utjecaj gospodarskog stanja u državi na povećan broj neizvršavanja financijskih obveza građana, a onda i na povećan broj blokiranih. Primjerice, istraživanje o financijskoj ranjivosti građana s obzirom na makroekonomsko okruženje pokazuje kako se u Hrvatskoj u razdoblju od 2005. do 2008 . zaduženost građana udvostručila, pri čemu se nezaposlenost pokazuje kao najvažniji čimbenik u nemogućnosti izvršavanja financijskih obveza, drugi je promjena deviznog tečaja, a treći pad odobrenih kredita (Bodul, Tomas Žiković, Žiković, 2015.: 136-140) $)^{9}$. Slično, i u empirijskim istraživanjima koja smo proveli u okviru pro-

\footnotetext{
${ }^{9}$ Pored toga, podaci FINE, koji se sustavno objavljuju od siječnja 2012., također upućuju na takve zaključke. Vidi detaljnije na: www.fina.hr/Default.aspx?sec=1801
} 
jekta Građanskopravna zaštita građana $u$ financijskoj krizi (dalje u radu: istraživanje GZGFK) ispitanici su također istaknute čimbenike označili kao one najčešće zbog kojih su pregovarali o reprogramiranju svojih financijskih obveza. Naime, na pitanje o razlozima reprogramiranja, najviše njih je kao razlog navelo gubitak posla. Distribucija ponuđenih odgovora prikazana je u grafikonu $1^{10}$ :

\section{Grafikon 1. \\ Razlozi reprogramiranja kreditnih zaduženja}

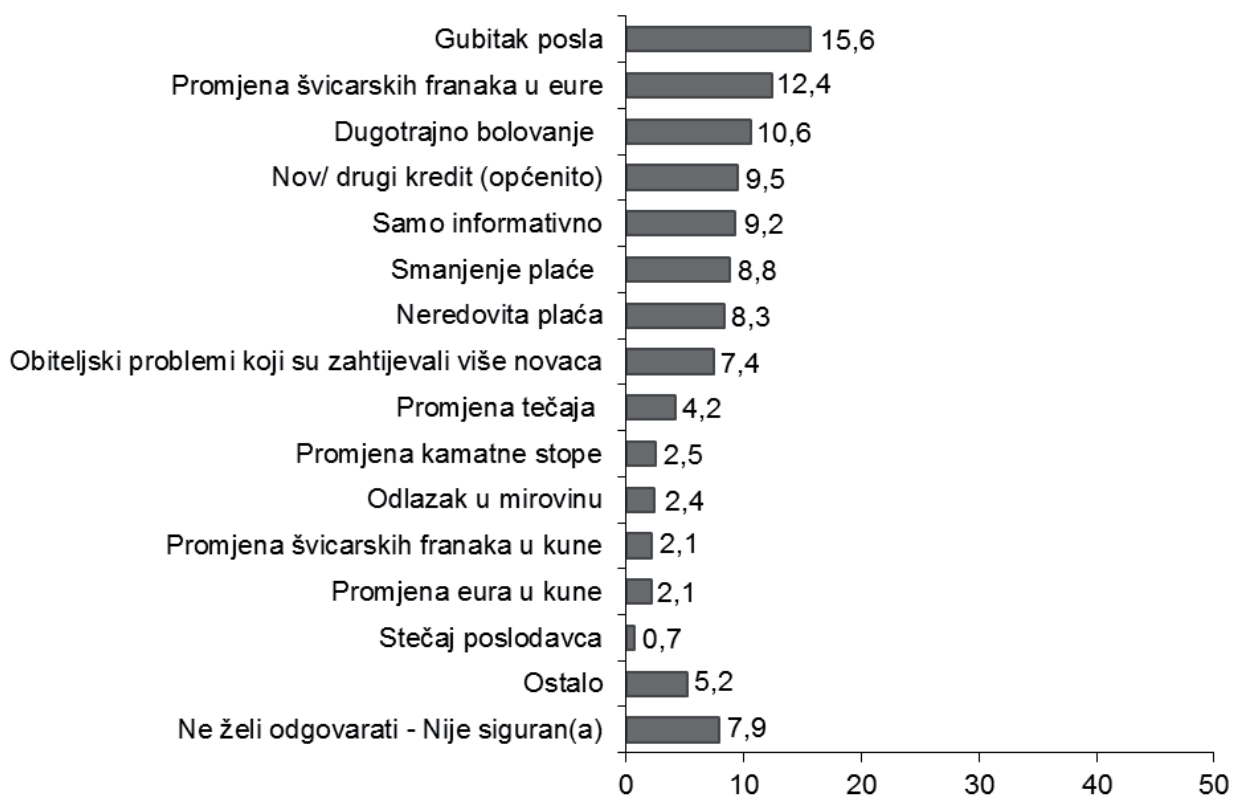

Izvor: Podaci za prikaz preuzeti su iz prezentacije Ipsos Public Affairs Iskustva građana s kreditima, izrađene na temelju rezultata ankete o financijskim uslugama.

Kako bi se spriječile ili ublažile takve posljedice krize, na razini Europske unije, ali i na državnoj razini počele su se uz primjenu postojećih, uvoditi nove mjere ${ }^{11}$.
Tako su na razini Europske unije osnovane savjetodavne službe za ublažavanje ili rješavanje problema osobne prezaduženosti te mjere za povrat duga (Bejaković,

\footnotetext{
${ }^{10} \mathrm{Na}$ ovo pitanje odgovarali su samo ispitanici koji su pod ovrhom, odnosno blokadom $(\mathrm{N}=64)$.

${ }^{11}$ Neke od tih mjera, uglavnom na načelnoj razini, određene su i Lisabonskim ugovorom (2009.). Primjerice, čl. 169. st. 1. i 2 glase: 1. Radi promicanja interesa potrošača i osiguravanja visokog stupnja zaštite potrošača, Unija prinosi zaštiti zdravlja, sigurnosti i gospodarskih interesa potrošača, kao i promicanju njihovih prava na informiranje, obrazovanje, te unutarnje organizacije radi ostvarivanja njihovih interesa. 2. Unija prinosi ostvarivanju ciljeva navedenih u stavku 1: a) mjerama koje se usvajaju u skladu s čl. 114. u okviru stvaranja unutarnjeg tržišta; b) mjerama kojima se podupiru, nadopunjuju i nadziru politike država članica (Hrvatska akademija znanosti i umjetnosti - Zavod za znanstveni i umjetnički rad u Splitu, 2009.)
} 
2016.: 138). S obzirom na nacionalnu razinu, mijenja se i uloga države. Naime, iako u procesu ostvarivanja vrijednosti sektorskog tržišta država sve više poprima ulogu regulatora, u vremenima financijske krize njezina uloga postaje sve važnija u očuvanju Ustavom utvrđenih socijalnih prava ${ }^{12}$ (Šućur, 2016.: 10).

Stoga je učinkovita i uspješna primjena svih tih mjera u ublažavanju posljedica financijske krize na europskoj i nacionalnim razinama jedan od pokazatelja učinkovitosti postojećih socijalnih i pravnih zaštita. To potvrđuje i niz istraživanja u području socijalne politike. Primjerice, istraživanja o učinkovitosti modela socijalne zaštite pojedinih država Europske unije u vrijeme posljednje financijske krize 2008. i 2009. godine pokazala su kako neučinkovita socijalna politika, a posebice neučinkoviti modeli socijalne zaštite, dovode do produbljivanja krize jer dolazi do povećanja izdataka socijalne zaštite, ponajviše naknada za siromaštvo i nezaposlenost (Šućur, 2016.). Postoje različite odredbe socijalne zaštite, ali mnogi autori se slažu kako ona čini temelj svake socijalne države. Prema ESSPROS-u ${ }^{13}$, socijalna zaštita obuhvaća sve intervencije javnih ili privatnih tijela koje imaju za cilj olakšati financijsko opterećenje kućanstva i pojedinaca nastalo djelovanjem niza definiranih socijalnih rizika i potreba. Osam je funkcija, a podaci pokazuju kako je u posljednjoj financijskoj krizi najveće povećanje izdataka socijalne zaštite bilo u sljedećim funkcijama: nezaposlenost, stanovanje te socijalna isključenost (Šućur, 2016.: 16). Razdoblja financijske krize, osim što pokazuju (ne)učinkovitost posto- jeće socijalne zaštite, prilika su i za redefiniranje slabo učinkovitih ili za uvođenje novih mjera. Ali, ne samo socijalnih mjera. Povećani izdaci u prethodno izdvojenim funkcijama socijalne zaštite zasigurno su dijelom posljedica prezaduženosti građana zbog korištenja financijskih usluga, kao i nemogućnosti podmirenja određenih usluga službi od općeg gospodarskog interesa. Primjerice, krajem 2016. u vrijeme istraživanja GZGFK, prema podacima FINE na dan 30. studenoga 2016. dug građana iznosio je 41,08 milijardi kuna, a broj blokiranih građana bio je 330 297. Od navedenog iznosa, $56,02 \%$ odnosilo se na dug građana prema bankama, odnosno prema telekomunikacijskim, komunalnim tvrtkama i tvrtkama za kartično poslovanje ${ }^{14}$. Drugim riječima, podaci pokazuju kako je veći dio duga građana posljedica korištenja različitih financijskih te usluga službi od općeg gospodarskog interesa, što dodatno opravdava i svako istraživanje o učinkovitosti pojedinih modela građanskopravne zaštite, a što je bio jedan od ciljeva provedenih empirijskih istraživanja.

Stoga se može s pravom pretpostaviti da, ako nije učinkovita primjena pravnih normi u području građanskopravne zaštite, ne može biti učinkovita niti socijalna zaštita građana. Kao podsjetnik, socijalna zaštita obuhvaća »sve intervencije javnih ili privatnih tijela koje imaju za cilj olakšati financijsko opterećenje kućanstva i pojedinaca«. U sprječavanju i rješavanju financijskih teškoća građana koji koriste financijske i/ili usluge službi od općeg gospodarskog interesa važnu ulogu imaju upravo mnoga javna i privatna tijela. $\mathrm{O}$

\footnotetext{
${ }^{12}$ Riječ je posebno o čl. 56.-60. Ustava Republike Hrvatske kojima se propisuju, među ostalim, pravo na zaradu te socijalnu sigurnost kao temeljnim osobnim pravima. O ustavnim normama vidi detaljnije Smerdel, Sokol, (2006.).

${ }^{13}$ European System of Integrated Social Protection Statistics.

${ }^{14}$ Udio duga građana prema bankama u odnosu na ukupni dug iznosio je 50,58\%, prema tvrtkama čija je djelatnost kartično poslovanje $1,99 \%$, telekomunikacijskim tvrtkama $2,70 \%$, a komunalnim tvrtkama $0,75 \%$. Vidi detaljnije na: www.fina.hr/Default.aspx?sec=1801.
} 
učinkovitosti njihova rada kao i o učinkovitosti primjene pravnih normi iz područja građanskopravne zaštite zasigurno ovisi i potreba ostvarivanja pojedinih socijalnih prava građana.

\section{POVEZIVANJE (GRAĐANSKO) PRAVNE I SOCIJALNE ZAŠTITE - NAČELO ZAŠTITE POTROŠAČA}

Istaknuto je da načelo zaštite potrošača, kako je ono zamišljeno i promovirano na europskoj razini kao jedno od temeljnih načela »europskog socijalnog modela«, podrazumijeva svojevrsno usklađivanje ekonomskih i socijalnih vrijednosti. Pravna zaštita potrošača koja se odnosi na financijske i usluge službi od općeg gospodarskog interesa samo je dio sustava zaštite potrošača koji je u posljednjem desetljeću doživio ekspanziju u propisima i tijelima, temeljem kojih se nerijetko na različite načine u različitim dijelovima pravnog sustava primjenjuje načelo zaštite potrošača (Baretić, 2015.: 74; Josipović, 2016.: 38). Takve razlike posebno su vidljive u korištenju istaknutih usluga. Upravo zbog toga što se radi o različitim normativnim rješenjima sektorske regulacije i instrumentima građanskopravne zaštite te različitoj ulozi države u donošenju i primjeni tih normi, u okviru istraživanja GZGFK provedene su i dvije ankete. Istraživanje je, uz financijske usluge, obuhvatilo i pojedine usluge službe od općeg gospodarskog interesa (mrežne industrije te opskrbu strujom i plinom). ${ }^{15}$ Povod je bila financijska kriza koja je zahvatila gotovo sve države Europske unije, a koja je doprinijela povećanju broja slučajeva osobne prezaduženosti.
Ranije je naznačeno kako je u socijalnoj politici kriza bila, zbog porasta zaduženja kod građana, svojevrsna prilika za vrednovanje učinkovitosti pojedinih modela socijalne zaštite, a na razini država članica Europske unije prilika za redefiniranje i preciziranje značenja pojedinih načela »europskog socijalnog modela«. Iako su obilježja i kriteriji osobne prezaduženosti različiti, postoje određeni općeprihvaćeni kvalitativni pokazatelji, kao na primjer stopa zaduženosti, odnosno postotak duga u odnosu na raspoloživ dohodak, sigurnost budućih dohodaka, kašnjenje u plaćanju režija, loša procjena kreditne sposobnosti potrošača, itd. (Bejaković, 2016.: 139-142). Propisima u Republici Hrvatskoj nisu izričito propisani kriteriji prezaduženosti građana. Ipak, posredno se ti kriteriji mogu tumačiti temeljem kriterija propisanih čl. 5.-7. Stečajnog zakon (NN, 71/2015., 104/2017.) te čl. 5. Zakona o stečaju potrošača (NN, 100/2015.). Riječ je o sljedećim kriterijima: nesposobnost za plaćanje koje postoji ako dužnik ne može duže od 60 dana, odnosno ako potrošač ${ }^{16}$ najmanje 90 dana ne može trajnije ispunjavati svoje obveze, te ako je imovina dužnika manja od postojećih dospjelih obveza.

Osim što su navedeni pokazatelji potencirani razdobljem krize, oni su ujedno i posljedica sve veće dostupnosti financijskih usluga te nedovoljne informiranosti građana o njihovim pravima i obvezama pri korištenju takvih usluga. $\mathrm{Na}$ ovakvu tezu upućuju mnoga istraživanja. Hodson, Dwyer i Neilson (2014.) tumače kako je financijska kriza samo ubrzala trend koji se već nekoliko desetljeća razvija u Americi, a odnosi se na povećanje korištenja financijskih usluga (posebno kredita), koji je Ame-

\footnotetext{
${ }^{15}$ Prilikom izrade teoretskog dijela istraživanja planirano je samo empirijsko istraživanje financijskih usluga. Iz gore navedenih razloga, neposredno prije provedbe ankete odlučili smo pitanja vezana za učinkovitost mjera usmjerenih na jačanje angažiranosti potrošača proširiti i na pojedine usluge službi od općeg gospodarskog interesa.

${ }^{16} \mathrm{O}$ značenju pojma potrošač u odnosu na dužnik detaljnije u: Mihelčić i Miščević (2016.).
} 
rikance od naroda štediša pretvorio u narod dužnika. Autori navode pojedine pozitivne posljedice kreditnog zaduživanja vezane za olakšavanje životnih poteškoća, međutim sve veća dostupnost kredita, nametljivost zajmodavaca u traženju novih tržišta čak i uz veliku vjerojatnost da bi otplata kreditnog duga mogla biti neizvjesna, dovode do niza negativnih posljedica poput povećanog financijskog rizika, stresa, depresije, socijalne isključenosti. Podaci o dostupnosti te informiranosti o financijskim uslugama dobiveni u okviru istraživanja GZGFK bit će prikazani u drugom dijelu rada. Ovdje ću navesti samo pojedine po- datke o kreditnim zaduženjima: od 1000 ispitanih građana njih 35\% su osobno korisnici kredita, a u 21\% kućanstava korisnik je neki drugi član, što znači da je ukupno $56 \%$ kućanstava kreditno zaduženo. Većina njih su korisnici jednog kredita, četvrtina dva, oko $10 \%$ ih ima 3 kredita, a 3\% četiri ili više. Pritom je važno spomenuti kako se u provedenoj anketi o financijskim uslugama manji dio ispitanika izjasnio da je radno aktivan - njih ukupno 431. Sljedeća tablica pokazuje broj kredita s obzirom na radni status te visinu primanja kod ispitanika koji su osobno korisnici kredita.

Tablica 1.

Broj kredita

\begin{tabular}{|c|c|c|c|c|}
\hline & & $\mathrm{N}$ & Jedan & Više od jednog \\
\hline \multicolumn{2}{|l|}{ Ukupno } & 350 & $62 \%$ & $38 \%$ \\
\hline \multirow{3}{*}{ Radni status } & Zaposleni & 238 & $58 \%$ & $42 \%$ \\
\hline & Umirovljenici & 84 & $68 \%$ & $32 \%$ \\
\hline & Ostali neaktivni * & 28 & $70 \%$ & $30 \%$ \\
\hline \multirow{5}{*}{$\begin{array}{l}\text { Primanja kućanstva } \\
\text { (u kn) }\end{array}$} & Do 4000 & 52 & $74 \%$ & $26 \%$ \\
\hline & $4001-7000$ & 99 & $61 \%$ & $39 \%$ \\
\hline & $7001-10000$ & 80 & $57 \%$ & $43 \%$ \\
\hline & Više od 10000 & 88 & $61 \%$ & $39 \%$ \\
\hline & Bez odgovora & 31 & $57 \%$ & $43 \%$ \\
\hline
\end{tabular}

* Zbog izrazito malog broja ispitanika, kućanice, studenti, nezaposleni i ostali morali su biti objedinjeni u jednu kategoriju.

Izvor: Podaci za prikaz preuzeti su iz prezentacije Ipsos Public Affairs Iskustva građana s kreditima, izrađene na temelju rezultata ankete o financijskim uslugama.

Iako je najveći postotak onih s dva ili više kredita kod zaposlenih s primanjima u prosjeku između 7000 i 10000 kuna, nije zanemariv postotak onih s više kreditnih zaduženja kod umirovljenika, radno neak- tivnih te onih s najnižim primanjima do 4 000 kuna.

S obzirom na visinu kreditnog zaduženja, 50\% zaposlenika podiglo je kredit u iznosu većem od 10000 eura, od kojih je 
$18 \%$ s primanjima do 4000 kuna. S iznosom većim od 10000 eura kreditno je zaduženo i $22 \%$ umirovljenika te $28 \%$ radno neaktivnih ispitanika. Pored navedenog, ovdje je važno izdvojiti i podatke o vrstama kredita. Naime, najviše ispitanika su korisnici nenamjenskih kredita $(32,6 \%)$, što su u pravilu krediti s najvećom kamatnom stopom i obično se koriste za pokrivanje životnih troškova. Ako se pritom usporedi struktura ispitanika s vrstama kredita, kod umirovljenika i radno neaktivnih ispitanika znatno je veći broj gotovinskih kredita nego kod zaposlenika, kao što je kod zaposlenih ispitanika najveći postotak tih kredita kod onih s primanjima do 4000 kuna. Potpuniji podaci o razlozima podizanja kredita po kategorijama ispitanika prikazani su u tablici 2. U tablici su izostavljeni podaci o ispitanicima koji su podigli kredit za kupnju druge nekretnine, poslovne opreme ili poslovnog prostora, podmirivanje troškova liječenja ili za neku drugu namjenu. Također, važno je istaknuti da su ispitanici koji imaju dva ili više kredita odgovarali na pitanje o kreditu s najvećim iznosom, što dakle ne isključuje kod pojedinih ispitanika mogućnost istodobnog postojanja i više kreditnih zaduženja.

Tablica 2.

Razlozi podizanja kredita

\begin{tabular}{|c|c|c|c|c|c|c|c|}
\hline & & $\mathrm{N}$ & $\begin{array}{c}\text { Za kup- } \\
\text { nju stana } \\
\text { u kojem } \\
\text { živim }\end{array}$ & $\begin{array}{c}\text { Za kupnju } \\
\text { automobila }\end{array}$ & $\begin{array}{c}\text { Za druge } \\
\text { namjene - } \\
\text { gotovinski } \\
\text { kredit }\end{array}$ & $\begin{array}{c}\text { Za ob- } \\
\text { novu, } \\
\text { adaptaciju } \\
\text { kuće, } \\
\text { stana }\end{array}$ & $\begin{array}{l}\text { Ne želi } \\
\text { odgovo- } \\
\text { riti - Nije } \\
\text { siguran(a) }\end{array}$ \\
\hline \multicolumn{2}{|l|}{ Ukupno } & 350 & $22 \%$ & $19 \%$ & $33 \%$ & $10 \%$ & $2 \%$ \\
\hline \multirow{3}{*}{ Radni status } & Zaposleni & 238 & $25 \%$ & $21 \%$ & $27 \%$ & $11 \%$ & $2 \%$ \\
\hline & Umirovljenici & 84 & $13 \%$ & $14 \%$ & $46 \%$ & $10 \%$ & $2 \%$ \\
\hline & $\begin{array}{l}\text { Ostali } \\
\text { neaktivni* }^{*}\end{array}$ & 28 & $15 \%$ & $23 \%$ & $38 \%$ & $1 \%$ & $0 \%$ \\
\hline \multirow{5}{*}{$\begin{array}{l}\text { Primanja } \\
\text { kućanstva } \\
\text { (u kn) }\end{array}$} & Do 4000 & 52 & $11 \%$ & $6 \%$ & $58 \%$ & $16 \%$ & $0 \%$ \\
\hline & $4001-7000$ & 99 & $15 \%$ & $18 \%$ & $36 \%$ & $13 \%$ & $1 \%$ \\
\hline & $7001-10000$ & 80 & $25 \%$ & $18 \%$ & $36 \%$ & $7 \%$ & $2 \%$ \\
\hline & Više od 10000 & 88 & $30 \%$ & $33 \%$ & $16 \%$ & $6 \%$ & $1 \%$ \\
\hline & Bez odgovora & 31 & $28 \%$ & $14 \%$ & $20 \%$ & $6 \%$ & $12 \%$ \\
\hline
\end{tabular}

* Zbog izrazito malog broja ispitanika, kućanice, studenti, nezaposleni i ostali morali su biti objedinjeni u jednu kategoriju.

Izvor: Podaci za prikaz preuzeti su iz prezentacije Ipsos Public Affairs Iskustva građana s kreditima, izrađene na temelju rezultata ankete o financijskim uslugama. 


\section{MODEL ODGOVORNOG KREDITIRANJA KAO MODEL ZAŠTITE OD PREKOMJERNE ZADUŽENOSTI GRAĐANA}

Porast slučajeva prezaduženosti građana koji nije samo posljedica utjecaja gospodarskih prilika, nego i široke dostupnosti financijskih usluga te nedovoljne informiranost potrošača o temeljnim karakteristikama financijskih proizvoda, doveo je do razvoja modela odgovornog kreditiranja. Riječ je o instrumentu za regulatorne reforme u normiranju i primjeni potrošačkih kredita koji je stekao dodatnu važnost i nove temelje u svjetlu globalne financijske krize. Mak (2015.) ističe političko značenje tog pojma jer nositelji politike putem modela odgovornog kreditiranja imaju tendenciju uravnotežiti nekoliko ciljeva financijskog sektora u svrhu odgovornog ponašanja svih sudionika na tržištu: financijsku uključenost, stabilnost financijskog sektora, integritet pružatelja financijskih usluga i financijsku zaštitu potrošača. To ujedno znači kako odgovorno kreditiranje pretpostavlja odgovornu regulaciju financijskog sektora čiji je nužan dio i zaštita od prekomjerne zaduženosti potrošača (Mak, 2015.: 411). Mnoga istraživanja pokazuju kako je financijska kriza izazvala niz sumnji u učinkovitost postojećih modela odgovornog kreditiranja, što je stvorilo potrebu za redefiniranjem pojedinih mjera kako bi se utjecalo na veću odgovornost kreditora u postupcima provjere, jasnije objašnjenje informacija te normiranje (Nield, 2010.). Pritom se nerijetko ističe potreba određivanja i uspostavljanja društveno odgovornog kreditiranja (Escrig-Olmeto, MuǹozTorres, Fernández-Izquierdo, 2012.).

Model odgovornog kreditiranja ustvari je model zaštite od prekomjerne zaduženosti potrošača. Kao model zaštite od prekomjerne zaduženosti potrošača on je, prije svega, model prevencije u većoj ili manjoj mjeri ostvarivan kroz sustav informiranja, odnosno financijskog obrazovanja. Stoga u primjeni tog modela kao i u analizi njegove društvene učinkovitosti prvenstveno treba ispitivati učinkovitost postojećih sustava informiranja, odnosno sustava koji nužno uključuje sve aktivnosti vezane za financijsko opismenjavanje. Kao posebna podtema istraživanja GZGFK model odgovornog kreditiranja obuhvatio je sljedeće mjere:

- mjere usmjerene na jačanje angažiranosti potrošača (eng. consumer engagement)

- mjere usmjerene na uređenje ponašanja financijskih subjekata (eng. industry-based requirements)

- mjere usmjerene na regulatornu kontrolu tržišta (eng. regulatory controls).

Istraživanje istaknutih mjera pretpostavlja primjenu načela zaštite potrošača te posebno naglašava jedan dio te primjene, a to je upravo informiranje i obrazovanje potrošača. Ta povezanost najočitija je u analizi učinkovitosti mjera za jačanje angažiranosti potrošača. Naime, početna pitanja koja su prethodila i uvjetovala kasniju izradu anketa u svrhu istraživanja primjene potonje mjere su:

- Jesu li postojeća pravila o informiranju potrošača u financijskom sektoru dovoljno jasna i razumljiva prosječnom potrošaču?

- Postoje li u ovom trenutku adekvatni osnovno i srednjoškolski programi edukacije usmjereni na financijsku pismenost te postoje li adekvatni programi financijskog opismenjavanja općenito?

- Je li postojeći sustav kolektivne zaštite potrošača učinkovit?

Odgovor na treće pitanje ustvari predstavlja odgovor na prva dva. U kojoj mjeri su pravila informiranja jasna i razumljiva 
prosječnom potrošaču može se iščitati iz rezultata istraživanja prikazanih u sljedećem odjeljku.

Za odgovor na drugo pitanje potrebno je upoznati zakonodavnu primjenu načela zaštite potrošača u dijelu koji se odnosi na mogućnosti i obvezu financijskog opismenjavanja građana pri korištenju financijskih usluga i pojedinih usluga službi od općeg gospodarskog interesa. Pored toga što naglašavanje učinkovitog informiranja i obrazovanja kao neizostavnog dijela modela odgovornog kreditiranja proizlazi iz europskih propisa u nastojanju istodobnog razvoja i svih načela europskog socijalnog modela, pa tako i načela zaštite potrošača, ono proizlazi i iz normativnog okvira koji je na snazi u Republici Hrvatskoj već osam godina. Upravo iz tog razloga, u obje ankete su pitanja o razumijevanju i poznavanju građanskopravne zaštite obuhvatila ponajviše to razdoblje, u kojem su stvorene mnoge normativne pretpostavke zaštite potrošača (Baretić, 2003., 2015.). Radi se o nizu novih zakona kojima se na drugačiji ili potpuno novi način određuju pojmovi poput »efektivne kamatne stope«, "potrošača«, »)ugovora o kreditu«, »dopuštenog prekoračenja«, »financijske usluge«, »utjecaja na ekonomsko ponašanje potrošača« itd., a čija su značenja dobrim dijelom usklađena s aktima Europske unije (čl. 3. Zakona o zaštiti potrošača, NN, 41/2014., dalje: ZZP; čl. 2. Zakona o potrošačkom kreditiranju, NN, 75/2009., 112/2012., 143/2013., 147/2013., 09/2015., 78/2015., 102/2015., 52/2016.). Nadalje, doneseni su i nacionalni strateški dokumenti, akcijski planovi, temeljem novih zakona imenovana su nacionalna tijela $i$ drugi dionici nadležni za sustavno provođenje aktivnosti vezanih za financijsko obrazovanje, odnosno opi- smenjavanje kojima bi se, među ostalim, trebala spriječiti i zaštititi (pre)zaduženost građana. Također, usvojeni su i propisani standardizirani obrasci o načinu i sadržaju informiranja građana ${ }^{17}$.

Temeljem čl. 1. ZZP-a, prava potrošača podrazumijevaju:

- pravo na zaštitu gospodarskih interesa potrošača

- pravo na zaštitu od opasnosti za život, zdravlje i imovinu

- pravo na pravnu zaštitu potrošača

- pravo na informiranje i edukaciju potrošača

- pravo na udruživanje potrošača u svrhu zaštite njihovih interesa

- pravo na predstavljanje potrošača i sudjelovanje predstavnika potrošača u radu tijela koja rješavaju pitanja od njihova interesa.

Nositelji zaštite potrošača temeljem čl. 124. ZZP-a su: Hrvatski sabor, Vlada, Ministarstvo gospodarstva, nadležne inspekcije, Nacionalno vijeće za zaštitu potrošača, poslovna udruženja, udruge za zaštitu potrošača, jedinice lokalne samouprave i ostala tijela javne vlasti. Učinkovita primjena svih tih prava, osim što ovisi o radu zakonodavnih te regulatornih službi od općeg interesa (gospodarskih i negospodarskih), ovisi i o provedbi niza nepravnih i socijalnih mjera. Jedna od takvih mjera, koju i mnogi autori ističu kao jednu od najvažnijih mjera prevencije prezaduženosti, jest financijsko obrazovanje. Mak, primjerice, tumači kod opće odredbe politike za hipotekarne kredite usklađene s EU direktivom, kako je ustvari riječ o politici koja je usmjerena na osiguravanje odgovornog ponašanja svih sudionika na financijskom tržištu - i zajmodavce i zajmoprimce. To podrazumijeva sprječavanje prevelike zaduženosti zajmo-

17 Takvi obrasci propisani su primjerice, čl. 3. Pravilnika o obvezi informiranja potrošača i o dodatnim pretpostavkama za izračun efektivne kamatne stope, NN, 14/2010. 
primatelja primjenom različitih regulatornih mehanizama i različitih sredstava kao što su pravni lijekovi u privatnom pravu ili nepravna sredstva kao što je obrazovanje (Mak, 2015.: 413). Pored odgovornog pozajmljivanja (što znači obvezu provjeravanja kreditne sposobnosti i financijskog stanja dužnika uglavnom putem kreditnih registara) te rane uključenosti kreditora $\mathrm{i} / \mathrm{ili}$ vjerovnika, Bejaković ističe kako prevencija obuhvaća i financijsko obrazovanje te osposobljavanje usmjereno na razvoj financijske pismenosti (Bejaković, 2016.).

Financijsko znanje je preduvjet financijske pismenosti, a financijsko obrazovanje je proces koji vodi procesu financijskog opismenjavanja koji Organizacija za ekonomsku suradnju i razvoj određuje: »Financijsko opismenjavanje je proces $\mathrm{u}$ kojem financijski potrošači/ulagači poboljšavaju svoje razumijevanje financijskih proizvoda i koncepata te putem informacija, uputa $\mathrm{i} / \mathrm{ili}$ objektivnih savjeta, razvijaju potrebne vještine i sigurnost kako bi postali svjesniji financijskih rizika i prilika, kako bi donosili utemeljene odluke, kako bi znali gdje se obratiti za pomoć te kako bi poduzimali druge učinkovite mjere za poboljšanje svoje financijske dobrobiti« (OECD, 2005.: 13). Ovu odredbu u potpunosti je preuzela i Vlada Republike Hrvatske $u$ dokumentu »Nacionalni strateški okvir financijske pismenosti potrošača za razdoblje od 2015. do 2020. godine $\ll(N N$, $11 / 2015$.). OECD detaljnije opisuje neke aktivnosti potrebne za razvoj financijskog opismenjavanja: Vlada i svi dionici trebali bi promovirati financijsku edukaciju s ciljem učinkovitog razvitka obrazovnih programa još od osnovne škole. Obrazovni programi i strategije financijskog obrazovanja trebali bi biti posebno usmjereni na aspekte životnog planiranja kao što su štednja, dugovi i osiguranje, kao i na specifične skupine korisnika i prilagodbu programa obrazovanja njihovim potrebama. Pored OECD-a, i Europska komisija se uključila $\mathrm{u}$ intenzivnije i sustavno promoviranje programa financijskog obrazovanja (European Commission, 2009.). Primjena predložene mjere trebala bi pridonijeti sprječavanju (pre)zaduženosti građana pa time i njihove financijske isključenosti koja se javlja u različitim oblicima, od nemogućnosti dobivanja bankovnih kredita do nedostupnosti financijskih usluga. Na taj način provedeno sprječavanje financijske isključenosti dovelo bi ujedno i do sprječavanja porasta socijalne isključenosti.

Što se tiče Republike Hrvatske, očito je da su stvorene normativne (i zakonske i strateške) pretpostavke za sveobuhvatnijim financijskim opismenjavanjem, iako ono nije niti na razini školskih programa niti na razini odgovornih tijela sustavno provedeno. U kojoj mjeri je takva provedba nužna kako bi se, među ostalim, prevenirao broj blokiranih i prezaduženih građana, pokazat će sljedeći rezultati.

\section{ISTRAŽIVANJE}

Slijedi opširniji prikaz rezultata o dostupnosti financijskih usluga, o poznavanju prava $\mathrm{i}$ obveza te načinu informiranja građana pri korištenju tih usluga i usluga pojedinih službi od gospodarskog interesa. Riječ je o rezultatima koji predstavljaju dobru osnovu za ocjenu učinkovitosti postojećeg modela odgovornog kreditiranja, u kontekstu teorijskog dijela projekta određenog i problematiziranog kroz mjere usmjerene na jačanje angažiranosti potrošača jer pružaju, među ostalim, jasne odgovore na pitanje o jasnoći i razumljivosti dobivenih informacija.

\section{Uzorak i ciljevi}

Prikupljanje podataka provedeno je metodom dviju telefonskih anketa posred- 
stvom Ipsos CATI sustava, profesionalnog sustava za telefonska istraživanja. Riječ je o anketi o financijskim uslugama i anketi o javnim i telekomunikacijskim uslugama. Istraživanje je provedeno u listopadu 2016. na nacionalnom reprezentativnom uzorku od 1000 ispitanika osoba starijih od 18 godina. Uzorak je reprezentativan s obzirom na šest regija (regije su kreirane na osnovi županija: Grad Zagreb; Sjeverna Hrvatska; Slavonija; Banovina, Kordun i Lika; Istra, Primorje i Gorski Kotar te Dalmacija) te s obzirom na veličinu naselja (četiri veličine naselja: do 2000 stanovnika, od 2001 do 10000 stanovnika, 10001 do 100000 stanovnika, više od 100000 stanovnika).

Ciljevi ankete bili su:

- dobiti uvid o kreditnoj zaduženosti građana (temeljem prikupljenih podataka o broju, vrstama i iznosima kredita) te korištenju drugih financijskih usluga banaka

- dobiti uvid u stupanj informiranosti potrošača o njihovim ugovornim pravima i obvezama

- prikupiti podatke o najčešće korištenim instrumentima osiguranja prilikom podizanja kredita ili ugovaranja drugih financijskih usluga banaka

- prikupiti podatke o korištenju prava na prijevremenu otplatu kredite te mogućnosti reprogramiranja kredita te poznavanju i korištenju instituta stečaja potrošača

- prikupiti podatke o broju građana čiji su računi pod ovrhom ili blokadom te o korištenju prava otvaranja zaštićenog računa

- dobiti uvid u stupanj informiranosti jamaca o njihovim ugovornim pravima i obvezama

- dobiti uvid u stupanj informiranosti potrošača o poznavanju općih uvjeta, odnosno o njihovim pravima i obvezama koje proizlaze iz korištenja javnih i telekomunikacijskih usluga
- dobiti uvid u načine ugovaranja javnih i/ili telekomunikacijskih usluga (putem interneta, telefonskim putem, u vlastitom domu)

- prikupiti podatke o broju i razlozima raskida ugovora za korištenje javnih usluga ili za korištenje telekomunikacijskih usluga te broju ovrha zbog neplaćenih računa za javne usluge.

\section{Tumačenje rezultata}

Anketa o financijskim uslugama provedena je od 12. do 21. listopada 2016. Sadržavala je pitanja o kreditnim zaduženjima po osobi, najvišem kreditu (vremenu podizanja, iznosu, roku otplate), korištenju sredstava po dopuštenom minusu, kreditnim karticama, načinima predugovornog informiranja građana, informiranosti jamaca, informiranosti o stvarima i pravima izuzetih iz ovrhe, instrumentima osiguravanja kredita, osiguranju od nezaposlenosti, alternativnim načinima otplate kredita te prisilnoj naplati tražbine.

Anketa o javnim i telekomunikacijskim uslugama provedena je od 12. do 26. listopada 2016. Tematske cjeline od kojih je koncipirana anketa o javnim i telekomunikacijskim uslugama su informiranost građana o općim uvjetima korištenja javnih usluga (vode, plina, električne energije), mogućnost podnošenja prigovora za obračun pojedinih javnih usluga, informiranost građana o općim uvjetima korištenja telekomunikacijskih usluga (fiksne i mobilne telefonije, internet), mogućnost podnošenja prigovora za korištenje tih usluga, načini sklapanja ugovora o korištenju javnih i/ili telekomunikacijskih usluga, prava i obveze koje proizlaze iz tih ugovora, raskid govora, neisporuka ugovorenih usluga, ovrha zbog neplaćenih računa te prava i obveze koje proizlaze iz ovršnog postupka. 
Slijedi prikaz rezultata o:

a. zaduženjima i dostupnosti financijskih usluga

b. načinu informiranja i (ne)razumijevanju informacija o pravima i obvezama građana pri korištenju usluga te

c. poznavanju temeljnih pojmova.

\section{Zaduženja i dostupnost financijskih usluga}

Podaci o kreditnim zaduženjima prikazani su u ranijem odjeljku. Međutim, rezultati istraživanja pokazuju kako nerijetko krediti nisu jedine financijske usluge koje građani koriste, odnosno jedina zaduženja koja imaju. Od svih ispitanika, 44,9\% je od- govorilo kako koristi sredstva raspoloživa po dopuštenom minusu - 16\% stalno, 7,7\% često, $11,4 \%$ povremeno i $9,8 \%$ rijetko. Od ukupnog broja ispitanih 333 je umirovljenika, od kojih 38\% stalno ili povremeno koristi sredstva raspoloživa po dopuštenom minusu, 95 je nezaposlenih, od kojih 30\% stalno ili povremeno koristi ta sredstva te 239 ispitanika s najnižim primanjima do 4 000 kuna, od kojih 37\% također stalno ili povremeno koristi sredstva raspoloživa po dopuštenom minusu. Što se tiče kreditnih kartica, većina koristi tu financijsku usluga: $35,1 \%$ ima jednu kreditnu karticu, 20,7\% dvije, a $8,9 \%$ tri ili više. Njih 34,1\% ne koristi kreditnu karticu. Prema kategorijama ispitanika podaci su prikazanu u sljedećoj tablici:

Tablica 3.

Broj kreditnih kartica

\begin{tabular}{|c|c|c|c|c|c|c|c|}
\hline & & $\mathrm{N}$ & $\begin{array}{c}\text { Niti } \\
\text { jednu }\end{array}$ & Jednu & Dvije & $\begin{array}{l}\text { Tri ili } \\
\text { više }\end{array}$ & $\begin{array}{l}\text { Ne želi odgovoriti } \\
\text { - Nije siguran(a) }\end{array}$ \\
\hline Ukupno & & 1000 & $34 \%$ & $35 \%$ & $21 \%$ & $9 \%$ & $1 \%$ \\
\hline \multirow{7}{*}{ Radni status } & Zaposleni & 431 & $24 \%$ & $43 \%$ & $24 \%$ & $9 \%$ & $0 \%$ \\
\hline & Umirovljenici & 333 & $35 \%$ & $35 \%$ & $20 \%$ & $10 \%$ & $0 \%$ \\
\hline & Kućanice & 70 & $57 \%$ & $18 \%$ & $14 \%$ & $7 \%$ & $4 \%$ \\
\hline & Studenti & 45 & $19 \%$ & $42 \%$ & $23 \%$ & $16 \%$ & $0 \%$ \\
\hline & Nezaposleni & 95 & $61 \%$ & $16 \%$ & $14 \%$ & $5 \%$ & $4 \%$ \\
\hline & Ostalo & 17 & $41 \%$ & $31 \%$ & $20 \%$ & $3 \%$ & $5 \%$ \\
\hline & Bez odgovora & 9 & $56 \%$ & $12 \%$ & $0 \%$ & $0 \%$ & $32 \%$ \\
\hline \multirow{5}{*}{$\begin{array}{l}\text { Primanja } \\
\text { kućanstva } \\
\text { (u kn) }\end{array}$} & Do 4000 & 239 & $52 \%$ & $29 \%$ & $15 \%$ & $4 \%$ & $0 \%$ \\
\hline & $4001-7000$ & 253 & $27 \%$ & $35 \%$ & $28 \%$ & $10 \%$ & $0 \%$ \\
\hline & $7001-10000$ & 174 & $26 \%$ & $35 \%$ & $25 \%$ & $14 \%$ & $0 \%$ \\
\hline & Više od 10000 & 168 & $22 \%$ & $43 \%$ & $23 \%$ & $12 \%$ & $0 \%$ \\
\hline & Bez odgovora & 166 & $40 \%$ & $35 \%$ & $13 \%$ & $6 \%$ & $6 \%$ \\
\hline
\end{tabular}

Izvor: Podaci za prikaz preuzeti su iz prezentacije Ipsos Public Affairs Iskustva građana s kreditima, izrađene na temelju rezultata ankete o financijskim uslugama. 
Na pitanje upućeno korisnicima kredita $(\mathrm{N}=350)$ je li im banka samoinicijativno nudila korištenje drugih financijskih usluga, njih $72,3 \%$ potvrdno je odgovorilo. $\mathrm{Na}$ pitanje o kojim financijskim uslugama je riječ, takve ponude najčešće su se odnosile na korištenje kreditne kartice $(77,3 \%)$, dopušten minus na tekućem računu $(51,8 \%)$ te korištenje još jednog kredita (22,5\%). Pritom nije zanemariv postotak nuđenja tih usluga kod socijalno najosjetljivijih ispitanika: od 350 korisnika kredita 84 je umirovljenika od kojih je $73 \%$ odgovorilo pozitivno, 28 radno neaktivnih od kojih je $89 \%$ također pozitivno odgovorilo te 52 zaposlenih ispitanika s najnižim primanjima od kojih je $74 \%$ potvrdilo nuđenje tih usluga. Podaci unutar pojedinih kategorija prikazani su u sljedećoj tablici $(\mathrm{N}=253)$

Tablica 4.

Ponude financijskih usluga banaka korisnicima kredita

\begin{tabular}{|c|c|c|c|c|c|}
\hline & & $\mathrm{N}$ & $\begin{array}{l}\text { Korištenje } \\
\text { kreditne kar- } \\
\text { tice }\end{array}$ & $\begin{array}{l}\text { Dopušten minus } \\
\text { na tekućem } \\
\text { računu }\end{array}$ & $\begin{array}{l}\text { Korištenje još } \\
\text { jednog kredita }\end{array}$ \\
\hline \multicolumn{2}{|l|}{ Ukupno } & 253 & $77 \%$ & $52 \%$ & $22 \%$ \\
\hline \multirow{3}{*}{ Radni status } & Zaposleni & 167 & $78 \%$ & $48 \%$ & $24 \%$ \\
\hline & Umirovljenici & 61 & $76 \%$ & $62 \%$ & $19 \%$ \\
\hline & Ostali neaktivni* & 25 & $79 \%$ & $54 \%$ & $22 \%$ \\
\hline \multirow{5}{*}{$\begin{array}{l}\text { Primanja ku- } \\
\text { ćanstva (u kn) }\end{array}$} & Do 4000 & 38 & $72 \%$ & $49 \%$ & $15 \%$ \\
\hline & $4001-7000$ & 78 & $75 \%$ & $45 \%$ & $18 \%$ \\
\hline & $7001-10000$ & 57 & $79 \%$ & $54 \%$ & $31 \%$ \\
\hline & Više od 10000 & 59 & $82 \%$ & $57 \%$ & $21 \%$ \\
\hline & Bez odgovora & 21 & $77 \%$ & $64 \%$ & $37 \%$ \\
\hline
\end{tabular}

* Zbog izrazito malog broja ispitanika, kućanice, studenti, nezaposleni i ostali morali su biti objedinjeni u jednu kategoriju.

Izvor: Podaci za prikaz preuzeti su iz prezentacije Ipsos Public Affairs Iskustva građana s kreditima, izrađene na temelju rezultata ankete o financijskim uslugama.

Među korisnicima kredita kojima su nuđene istaknute financijske usluge, većina je prihvatila korištenje kreditne kartice $\mathrm{i}$ dopuštenog minusa. Naime, od $77 \%$ ispitanika ( $\mathrm{N}=196)$ kojima su ponuđene kreditne kartice 51,9\% ih koristi, dopušteni minus po tekućem računu od $52 \%$ kojima je ponuđeno $(\mathrm{N}=131)$ koristi njih $62,8 \%$, te od $22 \%$ ispitanika $(\mathrm{N}=57)$ njih $27,7 \%$ je pri- hvatilo ponudu te podiglo još jedan kredit. S obzirom na očita zaduženja, ali i podatak koji je potvrdilo i ovo istraživanje, kako je najčešći razlog (pre)zaduženosti građana gubitak posla, zanimljiv je podatak kako samo $15,3 \%$ ispitanika od onih koji su ikada koristili kredit $(\mathrm{N}=537)$ imaju policu osiguranja od nezaposlenosti ili drugih situacija koje bi onemogućivale urednu ot- 
platu kredita, odnosno duga drugih financijskih usluga.

\section{Način informiranja $i$ (ne) razumijevanje informacija o pravima i obvezama građana pri korištenju usluga}

Na pitanje upućeno korisnicima kredita $(\mathrm{N}=350)$ jesu li upoznati da ih je banka dužna obavijestiti o svim pojedinostima kredita i prije nego što kredit bude odobren, $75,1 \%$ ih je potvrdno odgovorilo, $24,1 \%$ nije upoznato s tom obvezom banke, a $0,8 \%$ nije sigurno u odgovor. Od onih koji su potvrdno odgovorili, njih 70,9\% je informirano usmenim objašnjenjem djelatnika banke, $44,1 \%$ i/ili putem obrazaca banke, $5 \%$ ih se izjasnilo da uopće nije bilo informirano, dok ih se 3,7\% ne sjeća. Postotak potvrdnih odgovora gotovo je podjednak u svim kategorijama ispitanika izuzev kod radno neaktivnih (nezaposlenih, kućanica, studenata) gdje je taj postotak znatno niži i iznosi $50 \%$. Sto se tiče poznavanja Hrvatskog registra obveze po kreditima, među korisnicima kredita $(\mathrm{N}=350)$ veći dio njih $(57,2 \%)$ uopće nije čuo za navedeni registar.

$\mathrm{Na}$ pitanje ispitanicima koji su pisanim putem bili informirani o pravima i obvezama koje proizlaze iz ugovora o kreditiranju $(\mathrm{N}=155)$ jesu li pročitali obrazac banke, $42 \%$ je odgovorilo da je detaljno pročitalo, $47 \%$ da je pročitalo, ali ne detaljno, a $11 \%$ ispitanika da nije pročitalo ili se ne sjeća da su pročitali. Ispitanicima koji su bili ili pisanim ili/i usmenim putem informirani o pravima i obvezama koje proizlazi iz ugovora o kreditiranju ( $\mathrm{N}=280)$ postavilo se pitanje jesu li im informacije bile jasne i razumljive. Njih 56\% odgovorilo je da jesu u potpunosti, 30\% ispitanika ih je razumjelo u većoj mjeri, 11\% u manjoj mjeri, $2 \%$ ih nije razumjelo, a $1 \%$ je odgovorilo da se ne sjeća. Ispitanici $(\mathrm{N}=122)$ koji su odgovorili da im informacije nisu bile u potpunosti jasne i razumljive kao najčešće ponuđene razloge odabrali su kako su im informacije bile prestručno napisane i presložene $(51,4 \%)$, previše opsežne $(37 \%)$ te nedovoljno precizne (21\%). Jedno od prava koja proizlaze iz ugovora o kreditiranju je i mogućnost prijevremene otplate. Stoga smo građane koji su ikada koristili kredite $(\mathrm{N}=537)$ pitali jesu li bili informirani o mogućnosti prijevremene otplate kredita. Njih 44,5\% nije uopće bilo informirano o toj mogućnosti, 33,4\% je bilo informirano prije sklapanja kredita, a 14,8\% tijekom isplate kredita. Njih 7,3\% nije bilo sigurno.

$\mathrm{U}$ istraživanju je prilično velik broj ispitanika odgovorio da koristi dopušteni minus $(\mathrm{N}=449)$. Na pitanje jesu li ih u banci informirali o kamatnoj stopi i drugim uvjetima korištenja sredstava po dopuštenom minusu, njih 27,9\% je odgovorilo kako nisu bili informirani, $43,9 \%$ ih je informirano pisanim, a $38,1 \%$ usmenim putem. Od ispitanika koji su informirani pisanim putem $(\mathrm{N}=197)$, na pitanje jesu li detaljno pročitali obrazac banke o kamatnoj stopi i drugim uvjetima korištenja sredstava po dopuštenom minusa, njih tek $38,8 \%$ je potvrdno odgovorilo, 37,2\% je pročitalo, ali ne detaljno, a $24 \%$ ispitanika nije pročitalo ili se ne sjeća.

U anketi o javnim i telekomunikacijskim uslugama od ukupnog broja ispitanih građana njih $61,8 \%$ je odgovorilo da je upoznato s mogućnošću podnošenja prigovora za obračun javnih usluga, 37,5\% nije upoznato, dok $0,7 \%$ nije sigurno u odgovor. Međutim, na upit jesu li pročitali opće uvjete isporuke usluga kao što su npr. voda, plin i električna energija, samo $21,2 \%$ njih je odgovorilo da ih je pročitalo i da ih razumije, $6,6 \%$ ih je pročitalo, ali ne razumije, $28,7 \%$ nije niti znalo da opći uvjeti postoje, $37,5 \%$ ispitanika ti uvjeti ne zanimaju. Rezultati dobiveni ovom anketom pokazuju 
da su građani bolje informirani kod korištenja telekomunikacijskih usluga. Od svih ispitanih, $44,5 \%$ je pročitalo opće uvjete, $13 \%$ ne zna da takvi uvjeti postoje, a $29,6 \%$ ispitanika ti uvjeti ne zanimaju. S mogućnošću podnošenja prigovora upoznato je $72,5 \%$ ispitanika.

\section{Poznavanje temeljnih pojmova}

Jedan od pokazatelja koliko građani uistinu razumiju informacije o korištenju financijskih usluga svakako su i odgovori na sljedeća pitanja upućena svim ispitanicima $\mathrm{u}$ anketi o financijskim uslugama:

Grafikon 2.

Poznavanje pojmova

Znate li što je »efektivna kamatna stopa«?

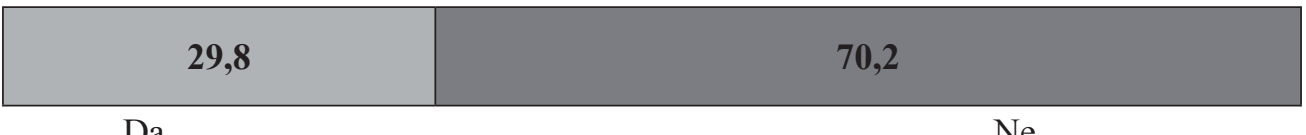

$\mathrm{Da}$ $\mathrm{Ne}$

Znate li što je »ukupni trošak zajma«?

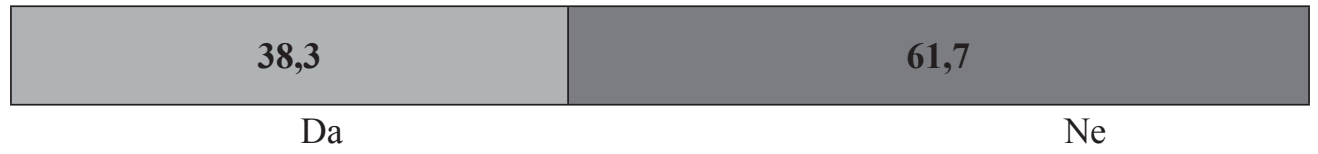

Grafikon 3.

Ovrha

Jeste li upoznati da postoje stvari na kojima se ne može provesti ovrha?

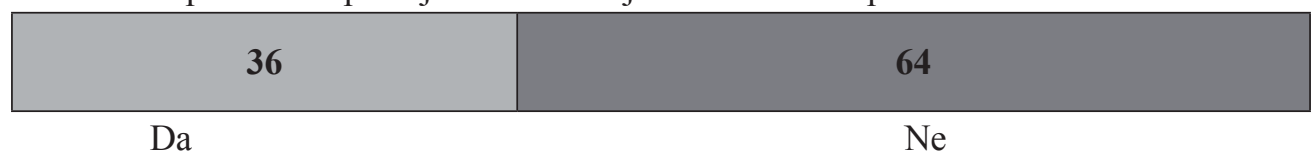

Jeste li upoznati da se na dijelu primanja ne može voditi ovrha?

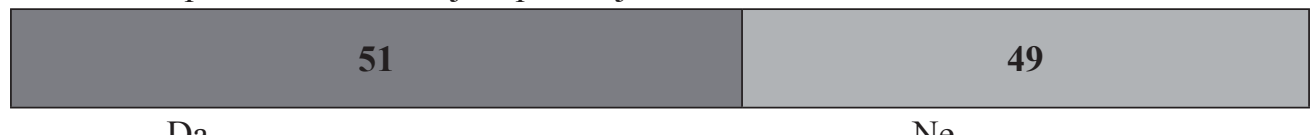

$\mathrm{Da}$

$\mathrm{Ne}$

Grafikonom 2. želim dodatno naglasiti koliki postotak ispitanika ne poznaje pojmove »efektivna kamatna stopa« te »ukupni trošak zajma«. Riječ je o pojmovima koji su neizostavni dio svakog ugovora o kreditiranju kao i ugovora o korištenju drugih financijskih usluga. Također, važno je istaknuti kako je postotak nepoznavanja tih pojmova puno manji kod zaposlenika s višim primanjima nego kod radno neaktivnih te zaposlenih ispitanika s najnižim pri- manjima. Tako pojam efektivne kamatne stope ne poznaje $80 \%$ umirovljenika, $75 \%$ kućanica i studenata, $77 \%$ nezaposlenih te $83 \%$ ispitanika s najnižim primanjima. Kod zaposlenika s primanjima od 7001 do 10 000 taj postotak je $52 \%$, a kod zaposlenika s primanjima višim od 10001 iznosi 57\%. Pojam »ukupni trošak zajma« ne poznaje $70 \%$ umirovljenika, $81 \%$ studenata, $73 \%$ kućanica, $65 \%$ nezaposlenih te $76 \%$ ispitanika s najnižim primanjima do 4000 kuna. 
Kod zaposlenika s primanjima od 7001 do 10000 postotak iznosi 48\%, a kod zaposlenika s primanjima višim od 10001 iznosi $51 \%$.

U pitanjima o ovrsi, pogotovo posljednjem, postotak poznavanja prava malo je veći. Međutim, samo u prosjeku, jer kod radno neaktivnih kao i kod ispitanika s najnižim primanjima postotak nepoznavanja je jednako visok. Tako $67 \%$ nezaposlenih i $76 \%$ ispitanika s najnižim primanjima ne zna da postoje stvari na kojima se ne može provesti ovrha (kod svih zaposlenika, pogotovo onih s najvišim primanjima taj postotak je 55\%). Nadalje, čak 68\% ispitanika s najnižim primanjima ne zna da se na dijelu primanja ne može provesti ovrha, dok taj postotak kod onih s primanjima između 7. 001 i 10000 iznosi 31\%, odnosno 32\% kod onih s primanjima iznad 10000 . Od svih pitanja o poznavanju pojedinih pojmova $\mathrm{i}$ instrumenata građanskopravne zaštite upućenih svim ispitanicima, samo na pitanje o poznavanju osobnog bankrota velika većina je odgovorila pozitivno. Međutim, mali je postotak onih koji bi se odlučio služiti tim instrumentom. Naime, njih čak $72,4 \%$ upoznato je da postoji osobni bankrot/ stečaj potrošača, od kojih bi samo njih $23,8 \%$ vjerojatno, a 7,4\% sigurno otišlo u stečaj, dok $56,4 \%$ vjerojatno ili sigurno ne bi. $\mathrm{Na}$ pitanje o razlozima nekorištenja navedenog prava, ispitanici su mogli izabrati više ponuđenih odgovora. Od svih ispitanika njih $63,8 \%$ je odgovorilo da bi pokušalo samostalno otplatiti dug, 25,5\% se ne bi odlučilo za stečaj iz straha da ne izgube imovinu, $12,3 \%$ jer su nedovoljno informirani, $7 \%$ zbog srama, 6,7\% zbog straha da se ne bi mogli ponovno kreditno zadužiti, 4,5\% je odgovorilo da se ne bi dovelo u takvu situaciju, itd.

\footnotetext{
${ }_{18}$ Vidi odredbu socijalne zaštite u odjeljku 2.1. rada
}

\section{ZAKLJUČAK}

Učinkovita primjena načela zaštite potrošača ovisi o učinkovitosti pravnih, ali i o učinkovitosti nepravnih modela zaštite predviđenih pravnom normom. To je posebno vidljivo na modelu odgovornog kreditiranja koji kroz svoju primarnu zadaću prevencije pretpostavlja postojanje nepravnih modela: razvijenog sustava informiranja, odnosno financijskog opismenjavanja. Razlog tome je, među ostalim, što mnoga istraživanja ukazuju na to kako neučinkovitost te preventivne funkcije bitno pridonosi porastu broja prezaduženih građana. Primjerice, Hodson, Dwyer i Neilson (2014.: 335-336) tumače kako su dugoročni problemi siromaštva dijelom potencirani neodgovornim i lako dostupnim kreditima, što se može riješiti transparentnijim sustavom kreditiranja kao i sustavnim promicanjem financijske pismenosti, odnosno obrazovanja u školama i na sveučilištima. Ishod ovakvih tumačenja jest da je razvoj učinkovitijeg informiranja i sustavnog obrazovanja, nerijetko obilježavan interdisciplinarnim pristupom (Lopes, Marques, 2011.: 528; Kus, 2015.), sve više u središtu promišljanja daljnjeg unaprjeđenja modela odgovornog kreditiranja. U skladu s tim, u radu je iznesena teza da u mjeri u kojoj je učinkovita primjena pravnih normi koje uređuju pravnu i nepravnu zaštitu, u toj mjeri je učinkovita i socijalna zaštita građana ${ }^{18}$.

U okviru istraživanja GZGFK primjena modela odgovornog kreditiranja istraživana je također kroz mjere usmjerene na jačanje angažiranosti potrošača. Naime, kao pokazatelj učinkovitosti tih mjera istaknuto je pitanje o jasnoći i razumljivosti informacija te pitanje o postojanju programa financijskog obrazovanja, o čemu je više bilo riječi u odjeljku 4. rada. Pritom je ta- 
kođer navedeno da se radi o pitanjima čiji odgovori predstavljaju mjerilo za ocjenu učinkovitosti kolektivne zaštite potrošača. Nažalost, predstavljeni rezultati upućuju na zaključak o neučinkovitosti postojeće zaštite. Razlozi su sljedeći:

Bez obzira na prilično dugo postojanje normativnih pretpostavki (propisa i nacionalnih strateških dokumenata), u Republici Hrvatskoj programi financijskog opismenjavanja nisu uvedeni niti na jednoj razini formalnog obrazovanja, niti je na bilo koji drugi način uvedeno sustavno financijsko opismenjavanje (izuzev pojedinačnih aktivnosti, npr. HANFE ${ }^{19}$ ) od strane tijela i subjekata koja su temeljem zakona obvezna uspostaviti takav sustav te osiguravati njegovu kontinuiranu provedbu.

Postojanje sve većeg broja propisa povećava broj informacija koje bi potrošač trebao razumjeti. Neupitno je kako se u okviru europskog i nacionalnih prava normira obveza da se potrošaču prije sklapanja ugovora dostavi prilična količina informacija (Baretić, 2015.: 82). Problem nije u tome izvršava li se ta obveza, nego na koji način i s kojim učinkom. Prikazani rezultati istraživanja GZGFK nedvojbeno pokazuju neučinkovitost postojećeg sustava informiranja s obzirom da velik postotak ispitanih građana ili ne razumije informacije ili ih te informacije ne zanimaju bez obzira jesu li te o načinu na koji su bili informirani (pisanim i/ili usmenim putem). Ako se usporedi postotak onih koji su se izjasnili da su im informacije u potpunosti bile jasne i razumljive s postotkom onih koji ne razumiju temeljne pojmove koji su nužan sadržajni dio svakog ugovaranja usluga, onda je otvoreno pitanje u kojoj mjeri su te informacije ispitanicima koji su potvrdno odgovorili doista i bile jasne. Pored navedenog, gotovo u svim odgovorima postotak neinformiranih znatno je veći kod socijalno najosjetljivijih skupina - radno neaktivnih građana, odnosno onih s najnižim primanjima do 4000 kuna.

I u Hrvatskoj postoji trend porasta korištenja i lakša dostupnost financijskih te usluga od općeg gospodarskog interesa koji je, prema podacima FINE, i kod nas jedan od najčešćih uzroka prezaduženosti građana. Istraživanje GZGFK je pritom pokazalo gotovo podjednaku dostupnost tih usluga $\mathrm{i}$ kod socijalno najosjetljivijih skupina ispitanika. Pored toga, iz dobivenih rezultata može se iščitati kako većina građana ne razumije niti pojmove niti prava i obveza temeljem kojih su uopće ostvarivali i ostvaruju pravo na korištenje svih tih usluga. I ovdje su rezultati pokazali kako je postotak takvoga nerazumijevanja znatno veći kod radno neaktivnih građana, odnosno kod onih građana s najnižim primanjima.

Zaključno, razvoj i primjena (građansko)pravne zaštite građana pri korištenju financijskih i drugih javnih usluga trebala bi pratiti sustavna primjena modela nepravne zaštite. Uvođenje sadržaja o financijskoj pismenosti u sustav obrazovanja te općenito razvoj sustavnog financijskog opismenjavanja po uzoru na najbolje europske prakse, nužan je put prema odgovornijem kreditiranju te prevenciji (pre)zaduženosti građana. Svođenje takvog sustava na propisane informativne letke i obrasce sadržane od pojmova čije značenje većina građana ne razumije ne dovodi do očekivanih društvenih učinaka. Jedno komparativno istraživanje o postojećim različitim načinima informiranja te različitim (obrazovnim) sadržajima financijskog opismenjavanja pomoglo bi učinkovitijem razvoju i primjeni zajedničkih načela modela odgovornog kreditiranja i europskog socijalnog modela.

\footnotetext{
${ }^{19}$ Godišnja izvješća HANFE. Vidi detaljnije na: http://www.hanfa.hr/publikacije/godisnje-izvjesce/ i http:// www.hanfa.hr/edukacija-i-zastita-potrosaca/.
} 


\section{LITERATURA}

Baretić, M. (2003). Implementacija prava Europske zajednice o zaštiti potrošača u hrvatsko pravo. U J. Barbić \& M. Giunio (ur.), Zbornik XLI. susreta pravnika (str. 223-259). Zagreb: Hrvatski savez udruga pravnika u gospodarstvu.

Baretić, M. (2015). Je li europsko uređenje ugovornog prava zaštite potrošača optimalni regulacijski okvir?. U J. Barbić (ur.), Zaštita potrošača u Republici Hrvatskoj (str. 73-103). Zagreb: Hrvatska akademija znanosti i umjetnosti.

Bejaković, P. (2016). Osobna prezaduženost u Europskoj uniji kao odrednica socijalne isključenosti. Revija za socijalnu politiku, 23(1), 137154. https://doi.org/10.3935/rsp.v23i1.1283

Bijela knjiga Europske unije o službama od općeg interesa - prvi dio. (2006). Hrvatska i komparativna javna uprava, 6(4), 35-49. https://hrcak.srce.hr/135925

Bijela knjiga Europske unije o službama od općeg interesa - drugi dio. (2007). Hrvatska i komparativna javna uprava, 7(1), 37-49. https:// hrcak.srce.hr/203450

Bodul, D., Tomas Žiković, I., \& Žiković, S. (2015). Socijalni i pravno-ekonomski aspekti uvođenja potrošačkog stečaja. Revija za socijalnu politiku, 22(2), 133-152. https://doi. org/10.3935/rsp.v22i2.1252

Bryde, B. O. (1993). Effektivität von Recht als Rechtsproblem. Berlin: De Gruyter.

Đulabić, V. (2007). Socijalne službe u konceptu službi od općeg interesa. Revija za socijalnu politiku, 14(2), 137-162. https://doi. org/10.3935/rsp.v14i2.679

Escrig-Olmedo, E., Muǹoz-Torres, M. J., \& Fernández-Izquierdo, M. Á. (2012). Sustainable development and the financial system: Society's perceptions about socially responsible investing. Business Strategy and the Environment, 22(6), 410-428. https://doi. org $10.1002 /$ bse. 1755

European Commission. (2004). White Paper on services of general interest. Commission of the European Communities, Brussels, 12.05.2004, COM (2004) 374 final.
European Commission. (2006). Communication from the Commission. Implementing the community Lisbon programme: Social services of general interest in the European Union. COM 177 final.

European Commission. (2009). The financial crisis and financial education report. Second Meeting of the Expert Group on Financial Education. Brussels: European Commission.

European Commission. (2013). The over-indebtedness of European households: Updated mapping of the situation, nature and causes, effects and initiatives for alleviating its impact. Brussels: European Commission.

European Union. (2006). Consolidated versions of the Treaty on European Union and of the Treaty establishing the European Community. Official Journal of the European Union, C 321, 29. 12. 2006. Available at https://www.ecb.europa.eu/ecb/legal/pdf/ ce32120061229en00010331.pdf

Europska komisija. (2017). Bijela knjiga o budućnosti Europe: Razmatranja i scenariji za EU27 do 2025. Dostupno na https://ec.europa. $\mathrm{eu} /$ commission/sites/beta-political/files/bijela_knjiga_o_buducnosti_europe_hr.pdf

Europska socijalna povelja. Narodne novine, br. $15 / 2002$.

Europska unija. (2009). Lisabonski ugovor. Adrias : zbornik radova Zavoda za znanstveni $i$ umjetnički rad Hrvatske akademije znanosti i umjetnosti u Splitu, 16, 1-418. https://hrcak. srce.hr/51081

Financijska agencija. (2016). Informacija o neizvršenim osnovama za plaćanje poslovnih subjekata i građana za studeni 2016. godine. Dostupno na: www.fina.hr/Default. aspx?sec $=1801$

Gutiérrez-Nieto, B., Serrano-Cinca, C., \& CamónCala, J. (2016). A credit score system for socially responsible lending. Journal of $\mathrm{Bu}$ siness Ethics, 133(4), 691-701. https://doi. org/10.1007/s10551-014-2448-5

Hodson, R., Dwyer, R. E., \& Neilson, L. A. (2014). Credit card blues: The middle class and the hidden costs of easy credit. Sociological Quarterly, 55(2), 315-340. https://doi. org/10.1111/tsq. 12059 
Hrvatska agencija za nadzor financijskih usluga. (2017). Godišnja izvješća. Dostupno na http:// www.hanfa.hr/publikacije/godisnje-izvjesce/

Josipović, T. (2016). Zaštita potrošača u ugovorima o potrošačkim kreditima koji se odnose na stambene nekretnine. U J. Barbić (ur.), Zaštita potrošača u Republici Hrvatskoj (str. 37-63). Zagreb: Hrvatska akademija znanosti i umjetnosti.

Koprić, I. (2009). Od javnih službi do službi od općeg interesa: nova europska regulacija i njezin odraz u modernim upravnim sustavima. U Zbornik radova Drugog skopsko-zagrebačkog pravnog kolokvija (str. 27-49). Skopje: Pravni fakultet Justinijan Prvi Sveučilišta Sv. Kiril i Metodij.

Koprić, I. (2014). Javne službe - službe od općeg interesa. U I. Koprić (ur.), Upravna znanost javna uprava u suvremenom europskom kontekstu (str. 215-247). Zagreb: Pravni fakultet.

Koprić, I., \& Đulabić, V. (2009). Modernizacija općeg upravnog postupka $i$ javne uprave $u$ Republici Hrvatskoj. Zagreb: Institut za javnu upravu; Društveno veleučilište u Zagrebu.

Kus, B. (2015). Sociology of debt: States, credit markets, and indebted citizens. Sociology Compass, 9(3), 212-223. https://doi. org/10.1111/soc4.12247

Lopes, D. S., \& Marques, R. (2011). How credit institutions look at society. European Societies, 13(4), 509-533. https://doi.org/10.1080/14 616696.2011 .580856

Mak, V. (2015). What is responsible lending? The EU Consumer Mortgage Credit Directive in the UK and the Netherlands. Journal of Consumer Policy, 38(4), 411-430. https://doi. org/10.1007/s10603-015-9301-9

Mihelčić, G., \& Miščević, E. (2016). Credere i kredit: dva srodna ili suprotstavljena pojma?. Zbornik Pravnog fakulteta Sveučilišta u Rijeci, 37(1), 317-365. https://hrcak.srce.hr/160659

Nacionalni program zaštite potrošača za razdoblje od 2013. do 2016. godine. Narodne novine, br. 90/2013.
Nacionalni strateški okvir financijske pismenosti potrošača za razdoblje od 2015. do 2020. godine. Narodne novine, br. 11/2015.

Nield, S. (2010). Responsible lending and borrowing: Whereto low-cost home ownership?. Legal Studies, 30(4), 610-632. https://doi. org/10.1111/j.1748-121X.2010.00165.x

Organisation for Economic Co-operation and Development. (2005). Improving financial literacy: Analysis of issues and policies. Paris: OECD.

Pravilnik o obvezi informiranja potrošača i o dodatnim pretpostavkama za izračun efektivne kamatne stope. Narodne novine, br. 14/2010.

Puljiz, V., Bežovan G., Matković, T., Šućur, Z., \& Zrinščak, S. (2008). Socijalna politika Hrvatske. Zagreb: Pravni fakultet.

Smerdel, B., \& Sokol, S. (2006). Ustavno pravo. Zagreb: Pravni fakultet.

Stečajni zakon. Narodne novine, br. 71/2015, 104/2017.

Šućur, Z. (2016). Uloga i izdaci socijalne zaštite u gospodarskoj krizi. Revija za socijalnu politiku, 23(1), 7-38. https://doi.org/10.3935/rsp. v23i1.1293

Ustav Republike Hrvatske. Narodne novine, br. 56/1990, 135/1997, 8/1998, 113/2000, 124/2000, 28/2001, 44/2001, 55/2001, 76/2010, 85/2010, $5 / 2014$.

Zakon o potrošačkom kreditiranju. Narodne novine, br. 75/2009, 112/2012, 143/2013, 147/2013, 09/2015, 78/2015, 102/2015, 52/2016.

Zakon o potvrđivanju Europske socijalne povelje. Narodne novine, br. 15/2002.

Zakon o stečaju potrošača. Narodne novine, br. $100 / 2015$.

Zakon o zaštiti potrošača. Narodne novine, br. 41/2014. 


\title{
Summary
}

\section{RESPONSIBLE INFORMATION AND FINANCIAL EDUCATION AS A MEASURE OF EFFICIENT CIVIL LAW AND SOCIAL CONSUMER PROTECTION}

\author{
Ksenija Grubišić \\ Faculty of Law, University of Zagreb \\ Zagreb, Croatia
}

There are various approaches to interpreting causes of the increasing over-indebtedness of citizens: economic, social and legal. Such an increase is certainly one of the consequences of the financial crisis. However, growing accessibility and variety of financial services, lack of understanding of terms, i.e. fundamental contractual rights and duties that arise out of contracting such services also contributes to the increase of indebtedness. Therefore, basic questions that the paper attempts to answer is: to what extent is the knowledge about rights and obligations of citizens who use financial and public services a credible measure of efficiency of civil law regulations which should, among other things, protect social rights, since their application affects over-indebtedness of citizens? The answers to the aforementioned question are largely based on the results of the research conducted in October 2016 within the project Civil Law Protection of Citizens in the Financial Crisis. The results have been analysed in the context of basic values expressed through individual principles of the responsible lending model, as well as individual principles of the European Social Model. The principle in focus is consumer protection which connects both models, and the realisation of which assumes certain harmonisation of particular parts of civil law protection and social protection of citizens. Based on the research results, the paper examines to what extent are certain civil law norms, particularly those that regulate the manner of informing citizens upon using financial and certain public services, socially efficient. That fosters the introduction of a more efficient legal and non-legal citizen protection in order to reduce their financial, and thus consequently their social exclusion.

Key words: model of responsible lending, European Social Model, consumer protection, financial services, public services, situational awareness, financial education and literacy. 